\title{
Investigation of a Chemically Regenerative Redox Cathode Polymer Electrolyte Fuel Cell using a Phosphomolybdovanadate Polyoxoanion Catholyte
}

\author{
Natasha L. O. Gunn, David B. Ward, Constantinos Menelaou, Matthew A. Herbert and \\ Trevor J. Davies*
}

\author{
Department of Natural Sciences, Faculty of Science \& Engineering, University of Chester, Thornton Campus, \\ Thornton Science Park, Pool Lane, Ince, Chester, CH2 4NU, United Kingdom. \\ *Corresponding Author: \\ Email: t.davies@chester.ac.uk \\ Tel: +44(0)1244 512297 \\ Fax: $+44(0) 1244511300$
}

To be submitted to the Journal of Power Sources 


\begin{abstract}
Chemically regenerative redox cathode (CRRC) polymer electrolyte fuel cells (PEFCs), where the direct reduction of oxygen is replaced by an in-direct mechanism occurring outside of the cell, are attractive to study as they offer a solution to the cost and durability problems faced by conventional PEFCs. This study reports the first detailed characterization of a high performance complete CRRC PEFC system, where catholyte is circulated between the cathode side of the cell and an air-liquid oxidation reactor called the "regenerator". The catholyte is an aqueous solution of phosphomolybdovanadate polyoxoanion and is assessed in terms of its performance within both a small single cell and corresponding regenerator over a range of redox states. Two methods for determining regeneration rate are proposed and explored. Expressing the regeneration rate as a "chemical" current is suggested as a useful means of measuring re-oxidation rate with respect to the cell. The analysis highlights the present limitations to the technology and provides an indication of the maximum power density achievable, which is highly competitive with conventional PEFC systems.
\end{abstract}

\title{
Keywords
}

Fuel cell; Regeneration; Chemically regenerative redox cathode, Polyoxometalate; Redox flow battery; Phosphomolybdovanadate polyoxoanion 


\section{Introduction}

It is widely accepted that system cost and durability are the principle challenges currently facing polymer electrolyte fuel cell (PEFC) commercialization [1, 2]. Such challenges are a consequence of oxygen being directly reduced at the cathode. This requires a high platinum catalyst loading and is the main cause of durability issues experienced by fuel cell developers. An alternative approach is to construct fuel cells with a chemically regenerative redox cathode (CRRC), utilising the indirect reduction of oxygen [3-6]. In these fuel cells, a liquid catalyst is reduced at the cathode and is subsequently re-oxidised via bubbling with air (where oxygen is reduced to water). The electrochemical reduction is relatively facile and can often be conducted at carbon, reducing the platinum requirement and cell cost. In addition, the absence of air at the cathode eliminates major mechanisms for fuel cell degradation, including high voltage transients at cell start-up and shutdown $[7,8]$ and chemical degradation of membranes via highly oxidative species $[9,10]$. The result of the CRRC modification is often a hybrid cell that resembles a hydrogen fuel cell at the anode and a redox flow battery at the cathode, with strong similarities to hydrogen-halogen flow batteries and vanadium-hydrogen regenerative fuel cells $[11,12]$. Figure 1 illustrates the CRRC fuel cell concept in the form of a system diagram (which includes the chemical species involved in this study - discussed later). The catholyte is subjected to repeated cycles of reduction and oxidation as it is circulated between the cell cathode and a gas-liquid oxidation reactor called the "regenerator". Thus, the power density of the system depends on the performance of both the fuel cell and the regenerator. Improving the latter involves a new set of challenges compared to those faced by fuel cell and flow battery engineers, where the objective is to develop an effective (i.e. high bubble surface area and fast oxidation reaction) and efficient (i.e. low parasitic energy consumption) bubbler.

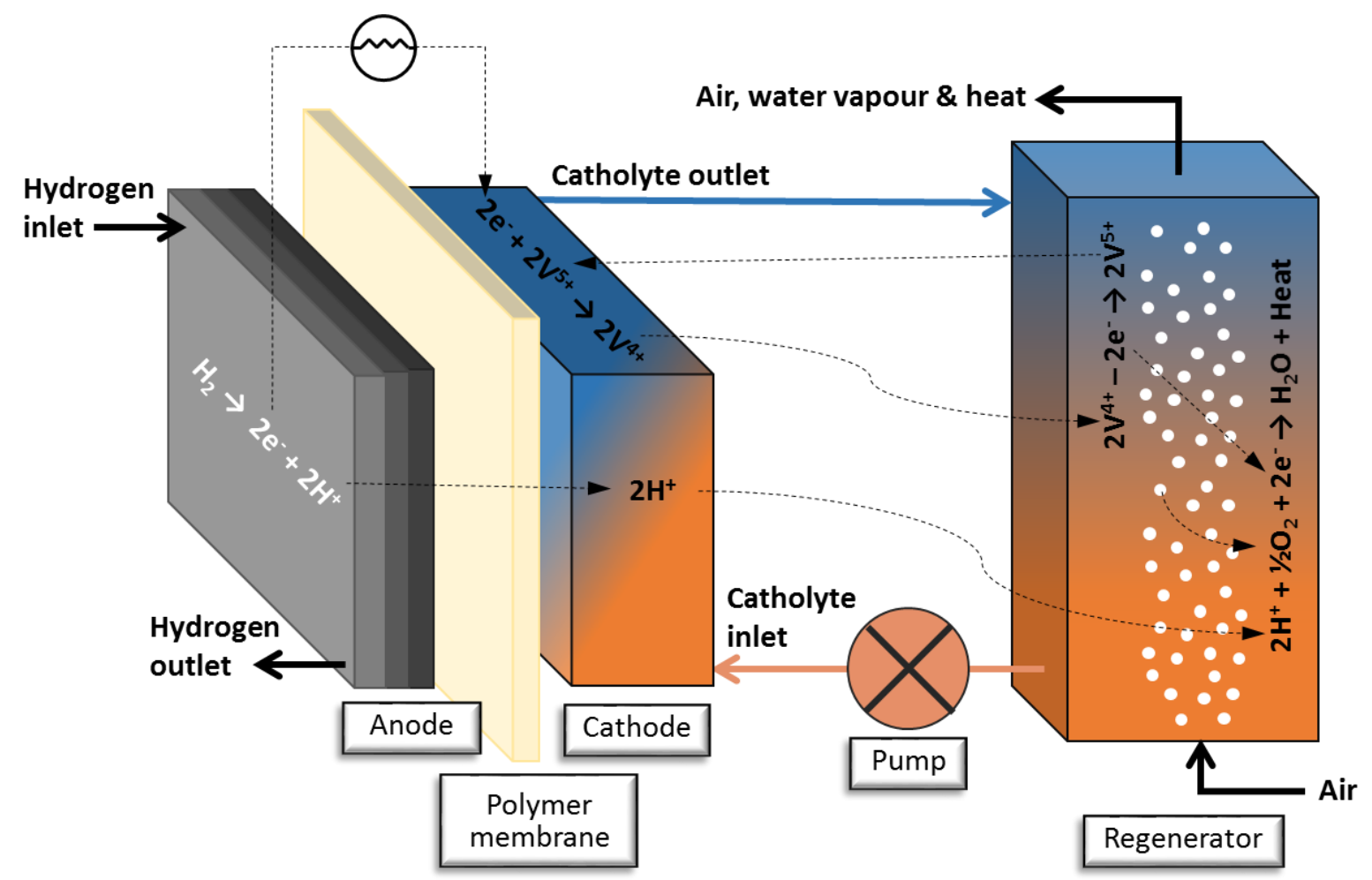

Figure 1. Schematic describing the CRRC process and including the reactions that occur within the cell, regenerator and catholyte solution. 
At first consideration. The CRRC approach may appear to add extra complexity and cost to the fuel cell system. However, in addition to the cost benefit of a platinum free cathode and the improved durability gained by in-directly reducing oxygen, the catholyte ensures the membrane is well hydrated. Consequently, there is no need to wet the hydrogen supply, removing the requirement for the gas humidity control common to conventional PEFC systems. The catholyte also offers advantages in terms of operational temperature and heat management. Conventional PEFCs often run at a maximum of $80^{\circ} \mathrm{C}$ as operation above this temperature can lead to unacceptable membrane proton conductivity (i.e. drying of the membrane). CRRC fuel cell membranes are always in contact with liquid so higher operation temperatures are possible, leading to faster electrode kinetics and more favourable conditions for waste heat rejection. Furthermore, the cooling requirement of conventional PEFC stacks necessitates the integration of intimately arranged liquid coolant channels throughout stack design, which increases the size, complexity and cost. However, in the case of CRRC fuel cells, the aqueous catholyte solution possesses a relatively high sensible heat capacity and hence, its circulation alone can be relied upon to absorb and transfer heat throughout the system. As such, the need for cooling can be satisfied external to the fuel cell stack by means of a simple inline heat exchanger.

Another potential disadvantage of CRRC fuel cells is the maximum open circuit voltage (OCV). For the regeneration reaction to proceed, the redox potential of the catholyte must be lower than the redox potential of oxygen (i.e. oxygen must oxidise the reduced catholyte) [13]. This limits the CRRC fuel cell OCV to approximately $1 \mathrm{~V}$, which is a typical OCV for a conventional PEFC [14]. However, as demonstrated by Weber and co-workers in their hydrogen bromine flow battery [15], substituting the slow electrode kinetics of oxygen reduction with a facile redox couple leads to a current-voltage curve where the initial slope is considerably shallower compared to the $\sim 200 \mathrm{mV}$ drop observed with conventional PEFCs, more than compensating for the lower OCV [16].

The first challenge in developing a CRRC fuel cell is selecting a catholyte [13]. The redox couple within the catholyte must have a high redox potential (but lower than +1.23 vs. the standard hydrogen electrode) and possess facile electrode kinetics, preferably at a low-cost electrode material (i.e. carbon). In addition, the reduced catholyte must react sufficiently fast with oxygen to allow high regeneration rates. Several catholyte systems have been reported and were recently reviewed [17]. In terms of cell power densities, only the $\mathrm{NO}^{3-} / \mathrm{NO}^{2-}$ and polyoxometalate (POM) systems have produced performance levels close to that of conventional PEFCs $[3,6]$, with POM systems the only CRRC technology to undergo commercialisation (via ACAL Energy Ltd) [16]. This report studies a CRRC PEFC using a vanadium-POM catholyte with empirical formula $\mathrm{H}_{6} \mathrm{PV}_{3} \mathrm{Mo}_{9} \mathrm{O}_{40}$, providing the most detailed description to date of a high performance CRRC fuel cell system. A similar fuel cell system was recently reported by Matsui et al. [18], although the fuel cell power density was relatively low compared to the best performing CRRC POM fuel cell in the present literature [6].

Although several POMs are suitable for CRRC fuel cell systems, including the catholyte used by Deng and co-workers in a biomass fuel cell [19], the most widely studied POM family for catalytic aerobic liquid phase oxidation applications are the keggin-type mixed-addenda heteropolyanions of general formula $\mathrm{PMo}_{12-n} \mathrm{~V}_{n} \mathrm{O}_{40}{ }^{(3+n)-}$, denoted HPA-n [20]. The $\alpha$-keggin structure is shown in Figure 2 and consists of a central tetrahedral $\mathrm{PO}_{4}$ ion surrounded by twelve $\mathrm{MO}_{6}$ distorted octahedra, where $\mathrm{M}$ is the metal (in this case either Mo or V). For a fully oxidised HPA- $n$, the Mo and V addendum atoms are in oxidation states 6 and 5, respectively, and the counter cations are often protons or a mixture of protons and Group 1 metal ions [21]. 


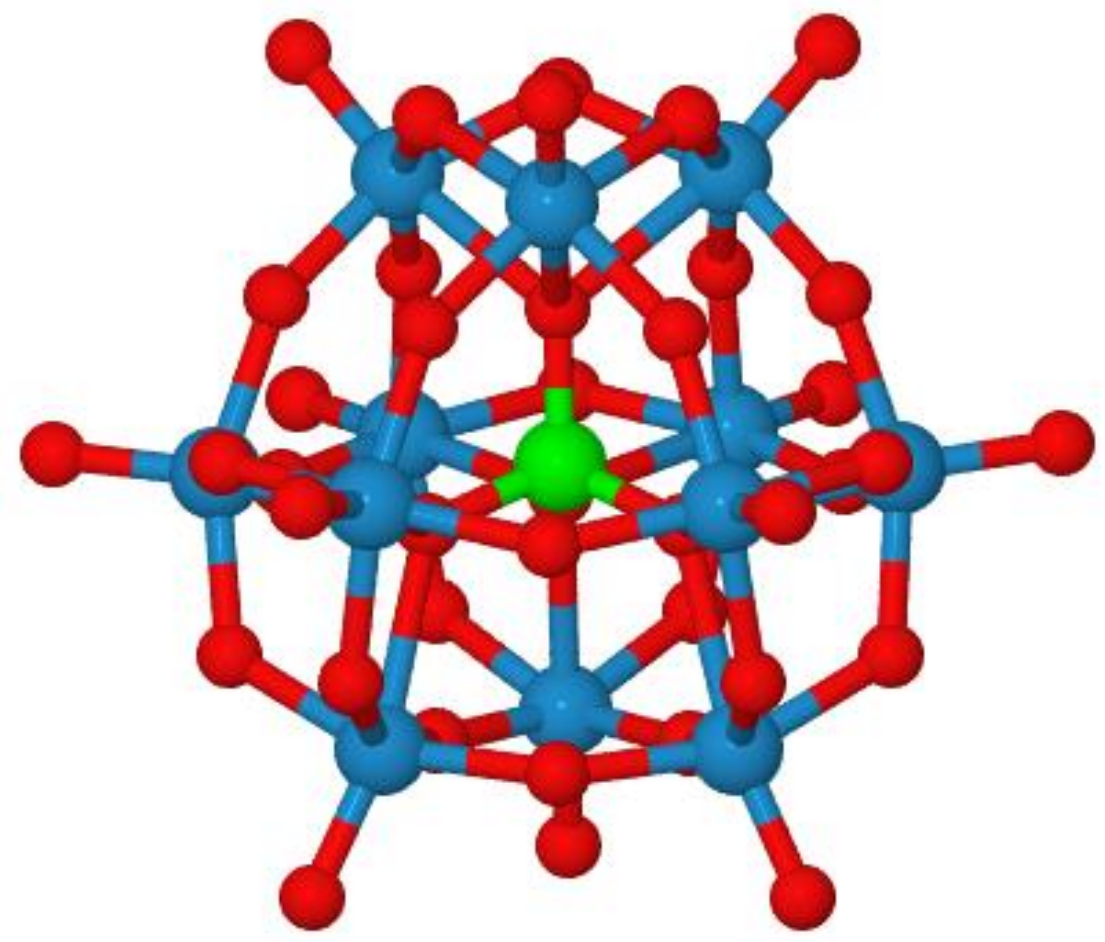

Figure 2. Representation of the $\alpha$-keggin structure $\left[\mathrm{PMo}_{12} \mathrm{O}_{40}\right]^{3-}$ with phosphorous in green, molybdenum in blue and oxygen in red. In $\left[\mathrm{PV}_{3} \mathrm{Mo}_{9} \mathrm{O}_{40}\right]^{6-}$ three vanadium atoms replace three molybdenum atoms (the hydrogens are omitted for clarity).

In a fully oxidized HPA-n, both the vanadium(V) and molybdenum(VI) sites can be (electrochemically) reduced and one POM anion can accept a relatively large number of electrons. This property of POMs has made them attractive to study for energy storage applications [22]. Furthermore, the electrochemical reduction of HPA- $n$ at carbon electrodes has relatively facile kinetics, a key requirement for CRRC catholytes [23-25]. Several voltammetric and electron paramagnetic resonance studies have shown the vanadium(V) sites are the first to accept electrons in electrochemical reduction, with the electrons (transferred individually) being localized on the vanadium atoms forming vanadium(IV) sites [23, 25-28]. For the purposes of this study we only consider the reduction of vanadium sites, i.e. a "fully reduced" or " $100 \%$ reduced" POM corresponds to an HPA- $n$ system where enough electrons have been provided to reduce all the vanadium sites. Matveev and co-workers proposed the following one electron, one proton pathway for the reduction of $\mathrm{PMo}_{12-n} \mathrm{~V}_{n} \mathrm{O}_{40}$ anions, where $1 \leq n \leq 4$ and $0 \leq m \leq 4$ [28]:

$$
\left[\mathrm{H}_{n+m-1} \mathrm{PV}_{m}^{\mathrm{IV}} \mathrm{V}_{n-m}^{\mathrm{V}} \mathrm{Mo}_{12-n} \mathrm{O}_{40}\right]^{4-}+\mathrm{e}^{-}+\mathrm{H}^{+} \leftrightarrow\left[\mathrm{H}_{n+m} \mathrm{PV}_{m+1}^{\mathrm{IV}} \mathrm{V}_{n-m-1}^{\mathrm{V}} \mathrm{Mo}_{12-n} \mathrm{O}_{40}\right]^{4-}
$$

The Mo and $\mathrm{V}$ addendum atoms are relatively labile and quickly move in and out of the keggin structure. Thus, equilibrium mixtures of POMs contain various HPA- $n$ anions, phosphates and free vanadium. For example, ${ }^{31} \mathrm{P}$ and ${ }^{51} \mathrm{~V}$ NMR studies of aqueous solutions of fully oxidised POMs with the empirical formula $\mathrm{H}_{5}\left[\mathrm{PV}_{2} \mathrm{Mo}_{10} \mathrm{O}_{40}\right]$ or $\mathrm{H}_{6}\left[\mathrm{PV}_{3} \mathrm{Mo}_{9} \mathrm{O}_{40}\right]$ have found equilibrium mixtures containing phosphate, $\mathrm{VO}_{2}{ }^{+}$(free vanadium) and un-protonated/partially protonated keggins $\mathrm{PV}_{1} \mathrm{Mo}_{11} \mathrm{O}_{40}$, $\mathrm{PV}_{2} \mathrm{Mo}_{10} \mathrm{O}_{40}$, and $\mathrm{PV}_{3} \mathrm{Mo}_{9} \mathrm{O}_{40}$ [29-33]. For reduced solutions, the situation is even more complicated. Both $\mathrm{VO}_{2}{ }^{+}$and $\mathrm{VO}^{2+}$ can be present as free vanadium and the different keggin structures can contain vanadium(V), vanadium(IV) or mixtures of vanadium(V) and (IV) [34]. Thus, the electrochemical reduction/oxidation of HPA-n systems also involves the one electron, two proton reaction of free vanadium: 


$$
\mathrm{VO}_{2}^{+}+\mathrm{e}^{-}+2 \mathrm{H}^{+} \leftrightarrow \mathrm{VO}^{2+}+\mathrm{H}_{2} \mathrm{O}
$$

For a CRRC fuel cell application, the POM speciation plays an important role in the electrochemical properties of the catholyte and influences the rate at which the reduced catholyte reacts with oxygen in the regenerator. The reduction of oxygen by reduced HPA- $n$ has been widely studied and is thought to proceed by a 3-electron pathway, producing ${ }^{\bullet} \mathrm{OH}$ radicals, for partially reduced HPA- $n$ (Reactions 3 and 4) and a 4-electron pathway for highly reduced HPA-n (Reaction 5) [35-37].

$$
\begin{aligned}
& {\left[\mathrm{H}_{n+2} \mathrm{PV}_{3}^{\mathrm{IV}} \mathrm{V}_{n-3}^{\mathrm{V}} \mathrm{Mo}_{12-n} \mathrm{O}_{40}\right]^{4-}+\mathrm{O}_{2} \rightarrow\left[\mathrm{H}_{n-1} \mathrm{PV}_{n}^{\mathrm{V}} \mathrm{Mo}_{12-n} \mathrm{O}_{40}\right]^{4-}+\mathrm{OH}^{\bullet}+\mathrm{H}_{2} \mathrm{O}} \\
& {\left[\mathrm{H}_{n} \mathrm{PV}_{1}^{\mathrm{IV}} \mathrm{V}_{n-1}^{\mathrm{V}} \mathrm{Mo}_{12-n} \mathrm{O}_{40}\right]^{4-}+\mathrm{OH}^{\bullet}+\rightarrow\left[\mathrm{H}_{n-1} \mathrm{PV}_{n}^{\mathrm{V}} \mathrm{Mo}_{12-n} \mathrm{O}_{40}\right]^{4-}+\mathrm{H}_{2} \mathrm{O}} \\
& {\left[\mathrm{H}_{n+3} \mathrm{PV}_{4}^{\mathrm{IV}} \mathrm{V}_{n-4}^{\mathrm{V}} \mathrm{Mo}_{12-n} \mathrm{O}_{40}\right]^{4-}+\mathrm{O}_{2} \rightarrow\left[\mathrm{H}_{n-1} \mathrm{PV}_{n}^{\mathrm{V}} \mathrm{Mo}_{12-n} \mathrm{O}_{40}\right]^{4-}+2 \mathrm{H}_{2} \mathrm{O}}
\end{aligned}
$$

Consequently, HPA- $n$ with the empirical formula of $\left[\mathrm{PMo}_{12} \mathrm{O}_{40}\right]^{3-}$ and $\left[\mathrm{PV}_{1} \mathrm{Mo}_{11} \mathrm{O}_{40}\right]^{4-}$ do not react with oxygen under mild conditions [20], with $n>1$ being a key requirement for HPA- $n$ catholytes in a CRRC fuel cell. Hence the selection of $\mathrm{H}_{6} \mathrm{PV}_{3} \mathrm{Mo}_{9} \mathrm{O}_{40}$ as the catholyte for this study. Free vanadium(IV), $\mathrm{VO}^{2+}$, can also reduce oxygen but at much slower rates than vanadium-keggins. Therefore, a key property of a POM catholyte is its vanadium-keggin (with $n>1$ ) content.

Figure 1 also shows the main reactions involved in the POM-CRRC PEFC process (where Reactions 15 have been simplified to highlight the vanadium(V)/(IV) transitions) and the proton/water balance. As in a conventional PEFC, hydrogen passes through a gas diffusion layer and is oxidised via a platinum catalyst at the anode, releasing protons and electrons. The protons then traverse the membrane, while the electrons travel to the cathode as an electrical current via an external circuit. However, instead of reducing gaseous oxygen to form water at the cathode, as per the convention, protons are transferred to the aqueous catholyte and the electrons reduce vanadium(V) to (IV) at the surface of a porous carbon electrode (for example, graphite felt). Hence, the cathodic reaction is 2-phase, as opposed to the 3-phase reaction in conventional PEFCs, and no platinum is required. The reduced catholyte (now high in vanadium(IV) concentration) leaves the cell and enters the regenerator where it is infused with fine air bubbles to promote oxygen mass transfer to solution. The oxygen reacts with the reduced catholyte forming water (and heat) and in so doing, oxidises vanadium(IV) to vanadium(V). Hence, by circulating the catholyte between fuel cell and regenerator, the constituent vanadium is induced to alternate between oxidation states. Note, for the catholyte concentration to remain constant, the evaporative losses of water in the regenerator must balance the rate of water produced via the reduction of oxygen. The key reactions can be abbreviated as follows, with the overall reaction being identical to that for conventional PEFCs:

Anode:

$\mathrm{H}_{2} \rightarrow 2 \mathrm{H}^{+}+2 \mathrm{e}^{-}$

Cathode:

$$
2 \mathrm{~V}^{5+}+2 \mathrm{e}^{-} \rightarrow 2 \mathrm{~V}^{4+}
$$

Regenerator:

$2 \mathrm{~V}^{4+}+2 \mathrm{H}^{+}+1 / 2 \mathrm{O}_{2} \rightarrow 2 \mathrm{~V}^{5+}+\mathrm{H}_{2} \mathrm{O}$

Overall System:

$$
\mathrm{H}_{2}+1 / 2 \mathrm{O}_{2} \rightarrow \mathrm{H}_{2} \mathrm{O}
$$


It is important to note that the catholyte itself is not the catalyst for the oxygen reduction reaction. Rather, vanadium containing keggin structures within the catholyte are the catalysts that alternate between the vanadium( $\mathrm{V}$ ) and vanadium(IV) oxidation states.

This investigation examines the suitability of aqueous $\mathrm{H}_{6} \mathrm{PV}_{3} \mathrm{Mo}_{9} \mathrm{O}_{40}$ as a catholyte within a complete CRRC PEFC system. The candidate catholyte is experimentally characterized by three key properties: i) redox potential vs. fraction of reduction, ii) regeneration rate (i.e. the rate of the vanadium reoxidation with air) and, iii) fuel cell performance (i.e. polarization curves and cell resistance). The results benchmark the technology against conventional PEFC systems and highlight ways to further develop this promising approach to energy conversion.

\section{Experimental}

\subsection{Catholyte Synthesis and Analysis}

The synthesis of $0.3 \mathrm{M} \mathrm{H}_{3} \mathrm{PV}_{3} \mathrm{Mo}_{9} \mathrm{O}_{40}$ (V3-POM) catholyte followed the "Metallomax" procedure disclosed in [38] and used deionised (DI) water (with a resistivity of $18.2 \mathrm{M} \Omega \mathrm{cm}$ ), $\mathrm{V}_{2} \mathrm{O}_{5}$ powder (99.2\%, Alfa Aesar, UK), Mo powder (99.9\%, Alfa Aesar, UK), $\mathrm{H}_{3} \mathrm{PO}_{4}$ (85.0\%, Sigma Aldrich, UK) and $\mathrm{MoO}_{3}$ (99.5\%, Alfa Aesar, UK). Concentration was evaluated gravimetrically using a $25 \mathrm{~mL}$ density jar (Jaytec Glass Ltd, UK) and pre-determined density vs. concentration calibration curve (density of V3POM at is $1.369 \mathrm{~g} \mathrm{~cm}^{-3}$ at $0.3 \mathrm{M}$ and $20^{\circ} \mathrm{C}$ ).

Fully oxidised V3-POM (obtained electrochemically via the reverse operation of the fuel cell) was analysed via ${ }^{31} \mathrm{P}$ NMR to determine the speciation in the aqueous solution [31]. Further details and spectra are provided in the Supporting Information (see Figure S5). The results are summarized in Table 1 and show the presence of $\mathrm{PV}_{1} \mathrm{Mo}_{11} \mathrm{O}_{40}(\mathrm{~V} 1), \mathrm{PV}_{2} \mathrm{Mo}_{10} \mathrm{O}_{40}(\mathrm{~V} 2), \mathrm{PV}_{3} \mathrm{Mo}_{9} \mathrm{O}_{40}\left(\mathrm{~V} 3\right.$ ) and $\mathrm{PV}_{4} \mathrm{Mo}_{8} \mathrm{O}_{40}$ (V4) keggins with considerable free vanadium $\left(\mathrm{VO}^{+}\right)$and a small amount of free phosphate. This agrees with previous results on similar systems [29, 31, 34].

\subsection{CRRC Fuel Cell Test Stand}

All fuel cell tests conducted throughout this study were carried out using an integrated CRRC fuel cell test stand (ACAL Energy, UK). Figure S1 presents a simplified Process and Instrumentation Diagram (P\&ID) of the test stand and a labelled photograph of the rig is provided in Figure S2. A key feature is the catholyte oxidation reactor, termed the "regenerator". Essentially a bubble column reactor, this consisted of a cylindrical glass vessel ( $55 \mathrm{~mm}$ internal diameter, $205 \mathrm{~mm}$ height) fitted with a POR 3 sintered glass sparge. The sparge head was cylindrical in design $(20 \mathrm{~mm}$ outer diameter, $50 \mathrm{~mm}$ height) mounted axially at the base of the vessel and fed via a $6 \mathrm{~mm}$ glass tube descending from above (ROBU Glasfilter-Geraete $\mathrm{GmbH}$, Germany). Figure S3 shows the basic concept design of the regenerator. Other than the architecture described, no other internal features were included (e.g. baffles plates). Re-oxidised catholyte was drawn from a port near the base of the reactor (beneath the zone of aeration), passed through a $25 \mu \mathrm{m}$ stainless steel filter (Swagelok, UK) and supplied to the fuel cell via a gear pump (Micropump, UK). Reduced catholyte, returning from the fuel cell, was fed to the roof of the vessel and travelled counter to the upward flow of the bubbles. The catholyte flow rate through the cell was $140 \mathrm{~mL} \mathrm{~min}^{-1}$, corresponding to a pumping pressure of $580 \mathrm{mbar}$. PFA tubing (1/4 inch) was used to transport the catholyte between the different rig components. Exhaust gas exited via parallel twin glass condensers, the purpose of which was to maintain target catholyte concentration by trapping/returning moisture and aerosols contained within the exhaust gas. The coolant, ethylene glycol, was maintained at $<5^{\circ} \mathrm{C}$ by circulation through a Peltier cooler. Regenerator 
liquid temperature was controlled to $80 \pm 2^{\circ} \mathrm{C}$ using a thermocouple mounted in the liquid at the reactor base.

Table 2 lists the general operating conditions employed throughout testing. Operated under these conditions, a regenerator gas hold-up ratio of 0.67 (i.e. $67 \%$ of the froth was gas) was determined based on the observable phase levels at the wall (the solution was sufficiently opaque to prevent further visualisation of the reactor interior). Bubbles visible at the glass wall were estimated to be approximately $600 \mu \mathrm{m}$ in diameter. Based on this bubble size and a gas hold-up volume of $190 \mathrm{~mL}$ (i.e. observable froth volume multiplied by 0.67 ), the reactor gas liquid interfacial area was determined as $\sim 1.9 \mathrm{~m}^{2}$ (assuming all bubbles are spherical).

Operating conditions were monitored and controlled using LabVIEW software (National Instruments, USA) via an on-board programmable logic controller (PLC). Instrument readings were logged each second. All instruments were calibrated prior to the investigation period.

The catholyte redox potential was continuously monitored using an in-line reference electrode similar to that described in [39]. This consisted of a mercurous sulphate reference electrode (Cambria Scientific, UK) immersed in a $0.1 \mathrm{M}$ sulphuric acid solution separated from a catholyte/JP945 carbon electrode (Merson UK, UK) via a Nafion ${ }^{\circledR}$ salt bridge. Potentials recorded with the mercurous sulphate reference electrode were adjusted to the normal hydrogen electrode, $\mathrm{NHE}\left(E_{\mathrm{Hg} / \mathrm{Hg}_{2} \mathrm{SO}_{4}}^{\circ}=650 \mathrm{mV}\right.$ vs. $\mathrm{NHE}$ at $\left.25^{\circ} \mathrm{C}\right)$.

$300 \mathrm{~mL}$ of catholyte at a concentration of $0.3 \mathrm{M}$ was added to the system, giving 0.09 moles of V3-POM and 0.27 moles of vanadium. Catholyte concentration was assessed at the start of each day of testing using the gravimetric method described above and adjusted as required by water top-up. Prior to the removal of each cell, the cathode was evacuated (pump ran in reverse) and rinsed though using DI water (resistivity of $18.2 \mathrm{M} \Omega \mathrm{cm}$ ).

A HCP 803 potentiostat (Bio-Logic, France) was used to control and monitor current load and cell voltage.

\subsection{Cell Build}

An expanded cell component diagram is given in Figure S4. The anode side of the cell build was similar to that of a conventional PEFC. This consisted of a stainless steel end plate, insulated from a current collector by a PTFE layer. The current collector was placed in direct contact with the back of the graphite flow field plate (a machined block of JP945, Mersen UK). The anode flow field was machined with serpentine flow channels to optimise hydrogen delivery to the back of a 34BC (SGL Group $\mathrm{GmbH}$, Germany) gas diffusion layer (GDL). The GDL was orientated so that the microporous layer was in contact with the catalyst layer on the membrane. A $0.35 \mathrm{~mm}$ elastomer gasket seal was fitted around the GDL between the anode graphite flow field block and membrane.

Typically, membrane electrode assemblies (MEAs) used in conventional PEFCs possess a platinum supported carbon (Pt/C) catalyst layer on each side of the membrane. However, as HPA- $n$ reduction has relatively facile kinetics on carbon, the cathode side of the membrane was bare. Therefore, with only their anode side coated, membranes used in this CRRC fuel cell system are referred to as anode membrane assemblies (AMAs). AMAs used in this study were reinforced Gore Primea (W. L. Gore \& Associates, Inc., USA) with an anode active area of $25 \mathrm{~cm}^{2}$ and Pt coating of $0.4 \mathrm{mg} \mathrm{cm}^{-2}$. 
The cathode side of the fuel cell was sealed using an elastomer gasket. The graphite cathode plate was machined from a block of JP945 (Mersen UK) with two parallel inlet and outlet channels running top and bottom of a $\sim 1 \mathrm{~mm}$ deep well. Each channel communicated with the well via a series of holes to evenly distribute the liquid flow across the well, resulting in a "plug flow" arrangement through the whole porous cathode (i.e. there was no flow field on the cathode side). A $5 \mathrm{~cm}$ wide by $6.2 \mathrm{~cm}$ long piece of GFD 2.5EA carbon felt (SGL Carbon GmbH, Germany) was placed in the well and acted as the porous carbon electrode (cathode) through which catholyte flowed. GFD 2.5EA is a non-woven material (made of graphitized carbon fibres of $\sim 8 \mu \mathrm{m}$ diameter) with a nominal thickness of $\sim 2.6 \mathrm{~mm}$, porosity of $\sim 95 \%$ and through plane electrical resistivity of $<6 \Omega \mathrm{mm}$. When compressed to $1 \mathrm{~mm}$ (i.e. in the cathode well), the porosity decreases to $88 \%$. In a detailed study of the electrochemistry of GFD 2.5EA, Smith et al. showed that a $1 \mathrm{~cm}^{2}$ section of the material has an approximate electrochemical surface area of $55 \mathrm{~cm}^{2}$ [42]. Assuming only the graphite felt directly underneath the active membrane (of $25 \mathrm{~cm}^{2}$ area) contributes to the cell current, this corresponds to a cathode electrochemical surface area of $\sim 1375 \mathrm{~cm}^{2}$. However, for the whole of this study, the "active area" of the cell refers to the membrane area, which is $25 \mathrm{~cm}^{2}$. As on the anode side, the remaining components consisted of a current collector, PTFE insulation layer and steel end plate. Sealing compression was applied using eight bolts (M6, $8 \mathrm{~mm}$ ), installed evenly about the perimeter of the steel end plates. Each cell was leak tested prior to installation and operation. The compression pressure on the active area was determined to be 3.5-4 bar via measurements with a Tekscan I-Scan pressure pad (Tekscan Inc., USA) inserted inside a replica cell build in place of the membrane.

\subsection{Determining Cell Performance at Various Catholyte Oxidation States}

Cell performance was evaluated via polarization $(I-V)$ curves and electrochemical impedance spectroscopy. As cell performance was expected to vary with the fraction of vanadium(IV), cell polarization curves were obtained at several target catholyte redox states. For this purpose, a Redox Potential vs. Fraction Vanadium(IV) calibration curve was generated (i.e. a redox calibration curve). The catholyte was electrochemically oxidised to over 99\% vanadium(V) (confirmed via UV-Vis spectroscopy) by supplying a reverse current to the cell (a 'sacrificial' cell was used for this specific purpose). Then, catholyte vanadium was incrementally reduced by the application of a fixed current density over repeated fixed time intervals (i.e. cycles of $0.12 \mathrm{~A} \mathrm{~cm}^{-2}$ for $225 \mathrm{~s}$ followed by $150 \mathrm{~s}$ at open circuit). Throughout this process, the regenerator was supplied with nitrogen to avoid any reaction with atmospheric oxygen. The catholyte potential vs. fraction vanadium(IV) was calculated assuming $100 \%$ current efficiency.

Table 3 gives the target vanadium(IV) fractions and respective catholyte potentials at which polarization curves were generated. Prior to each test, catholyte potential was adjusted to the pertinent target value by either reduction at the cathode or oxidation within the regenerator. Where values were found to be beyond that achievable by the regenerator, targets were reached through electrochemical oxidation (i.e. 'sacrificial' cell and applied reverse current flow).

During each polarisation curve test, the current density increased at a rate of $0.02 \mathrm{~A} \mathrm{~cm}^{-2} \mathrm{~s}^{-1}$ until the cell voltage declined to $200 \mathrm{mV}$ (or the load reached $3.2 \mathrm{~A} \mathrm{~cm}^{-2}$ ). Cell voltage was recorded every 0.1 s. To help maintain target catholyte potentials against the reductive reaction occurring at the cathode, the regenerator was activated as required.

Electrochemical impedance spectroscopy (EIS) was carried out at a target inlet vanadium(IV) fraction of 0.65 , although varying the catholyte potential had little effect on the impedance results. The 
impedance range was $30 \mathrm{kHz}-20 \mathrm{mHz}$, with 6 points per decade and a current range of $80 \mathrm{~A}$. Spectra were obtained at $0.35,0.6$ and $1 \mathrm{~A} \mathrm{~cm}^{-2}$ (corresponding to $8.75,15$ and $25 \mathrm{~A}$ ).

\subsection{Catholyte Regeneration Rate Quantification}

Regenerator oxidation performance can be quantified in several ways (e.g. rate of oxygen consumption or the rate of vanadium(IV) conversion to vanadium(V)). For a CRRC fuel cell system, a useful measure of regeneration rate is to consider the movement of electrons. Within a system operating at steady-state, the rate of electron transfer within the cell must equal that within the regenerator. With respect to the cell, this is determined by the current load and is measured in amperes. It follows that re-oxidation within the regenerator can be quantified by a "chemical current" or "regeneration current". As such, the cell (or stack) load can be directly related to the regenerator and vice versa.

The rate of oxidation within the regenerator can be expected to increase with the fraction of vanadium in the IV oxidation state (i.e. the reactive species), where the fraction of vanadium(IV) is defined as the total concentration of vanadium in the 4+ oxidation state divided by the total concentration of vanadium. Conversely, cell voltage can be expected to decrease as the redox potential of the catholyte declines with an increasing fraction of vanadium(IV).

\subsubsection{Evaluating the regeneration current}

Two methods of determining the regeneration current $\left(I_{R}\right)$ were developed and applied. These were the Steady-State Method and the Regeneration Sweep Method. In the Steady-State Method, a stepped series of increasing current loads was applied to the cell. At each step, the rate of oxidation within the regenerator reached equilibrium with the rate of electrochemical reduction within the cell, resulting in a constant catholyte redox potential. At this point the measured current drawn from the cell, $I$, was deemed to equal that of the regeneration, $I_{R}$. The corresponding potential vs. inline reference electrode was noted and the vanadium(IV) fraction determined using the redox calibration curve. Cell loads applied in this way were $0.04,0.08,0.16,0.24,0.32$ and $0.48 \mathrm{~A} \mathrm{~cm}^{-2}$.

The Regeneration Sweep Method determines $I_{R}$ by examining the rate of change of vanadium(IV) fraction over a range of vanadium(IV) fractions. First, the catholyte was electrochemically reduced using the cell until a vanadium(IV) fraction of 0.85 was achieved. During this stage, re-oxidation was prevented by the supply of pure nitrogen to the regenerator. With catholyte following and the cell at open circuit, the regenerator gas supply was then switched to air and the oxidation reaction allowed to progress. The catholyte then "swept" through a range of vanadium(IV) fractions at a rate related to the regeneration current, $I_{R}$, by the following equation.

$$
I_{\mathrm{R}}=\frac{d Q_{R}}{d t}=V[\mathrm{POM}] n F \frac{d \theta}{d t}
$$

where $Q_{R}$ is the equivalent charge passed due to the oxidation reaction, $t$ is time, $V$ is the volume of catholyte, $[\mathrm{POM}]$ is the concentration of POM, $n$ is the number of vanadium centres in the POM empirical formula (for V3-POM, $n=3$ ), $F$ is Faraday's constant and $\theta$ is the fraction of vanadium(IV) (determined using the redox potential calibration curve described above). Analysis of the regeneration sweep data gave $I_{R}$ as a function of fraction vanadium(IV). Three repeat tests were performed using this Regeneration Sweep method. 
The Steady-State Method is perhaps the more accurate means of measuring regeneration performance as it relies on fewer key assumptions, however, in practice the data is time consuming to collect as each equilibrium redox state is approached asymptotically and can take hours to achieve. Within this time, the performance of other system components can change, hence shifting the point of equilibrium (e.g. changes in sparge performance, gas-liquid hold-up and/or bubble size). By contrast, an entire Regeneration Sweep test can be completed in $\sim 40$ minutes. Therefore, this investigation also assessed the closeness of agreement between the two approaches to validate the method and results of each.

\subsection{Ex-situ Conductivity, Redox and pH Analysis}

On conclusion of all cell and regenerator testing, the V3-POM catholyte was once again electrochemically adjusted (using the cell) to the vanadium(IV) fractions $0.05,0.45,0.65$ and 0.85 . After each adjustment, a $25 \mathrm{~mL}$ catholyte sample was removed from the regenerator and bottled under nitrogen to maintain its oxidation state. Samples were then heated to $80^{\circ} \mathrm{C}$ using a water bath, before the $\mathrm{pH}$, conductivity and redox potential measurements were taken at each respective temperature. The $\mathrm{pH}$ was measured using an $827 \mathrm{pH}$ Lab (Metrohm, UK) (following calibration with pH 1 and pH 2 buffers), conductivity using a pHenomenal CO1300L (VWR International, UK) and redox potential using a mercurous sulphate reference electrode arrangement as described above, a JP945 graphite rod (Merson UK, UK) and a 117 True RMS Multimeter (Hanna Instruments, UK). 


\section{Results \& Discussion}

\subsection{Regeneration Performance}

Figure 3 illustrates a plot of the vanadium(IV) fraction in V3-POM vs. the catholyte potential (at $80^{\circ} \mathrm{C}$ ) as recorded by the reference electrode (adjusted to the normal hydrogen electrode). Also shown is the corresponding plot for cell OCV. The two curves almost overlap, with the difference most likely caused by a changing junction potential (with $\mathrm{pH}$ ) associated with the in-line reference electrode. As expected, the catholyte potential decreases as the fraction of vanadium(IV) increases. Although the curves in Figure 3 suggest a Nernstian behaviour (as expected), it proved too difficult to fit a Nernsttype equation to the experimental data, for reasons discussed in the Supporting Information. Rather, to numerically describe this relationship, the data was fitted against a $6^{\text {th }}$ order polynomial, which was used in subsequent calculations.

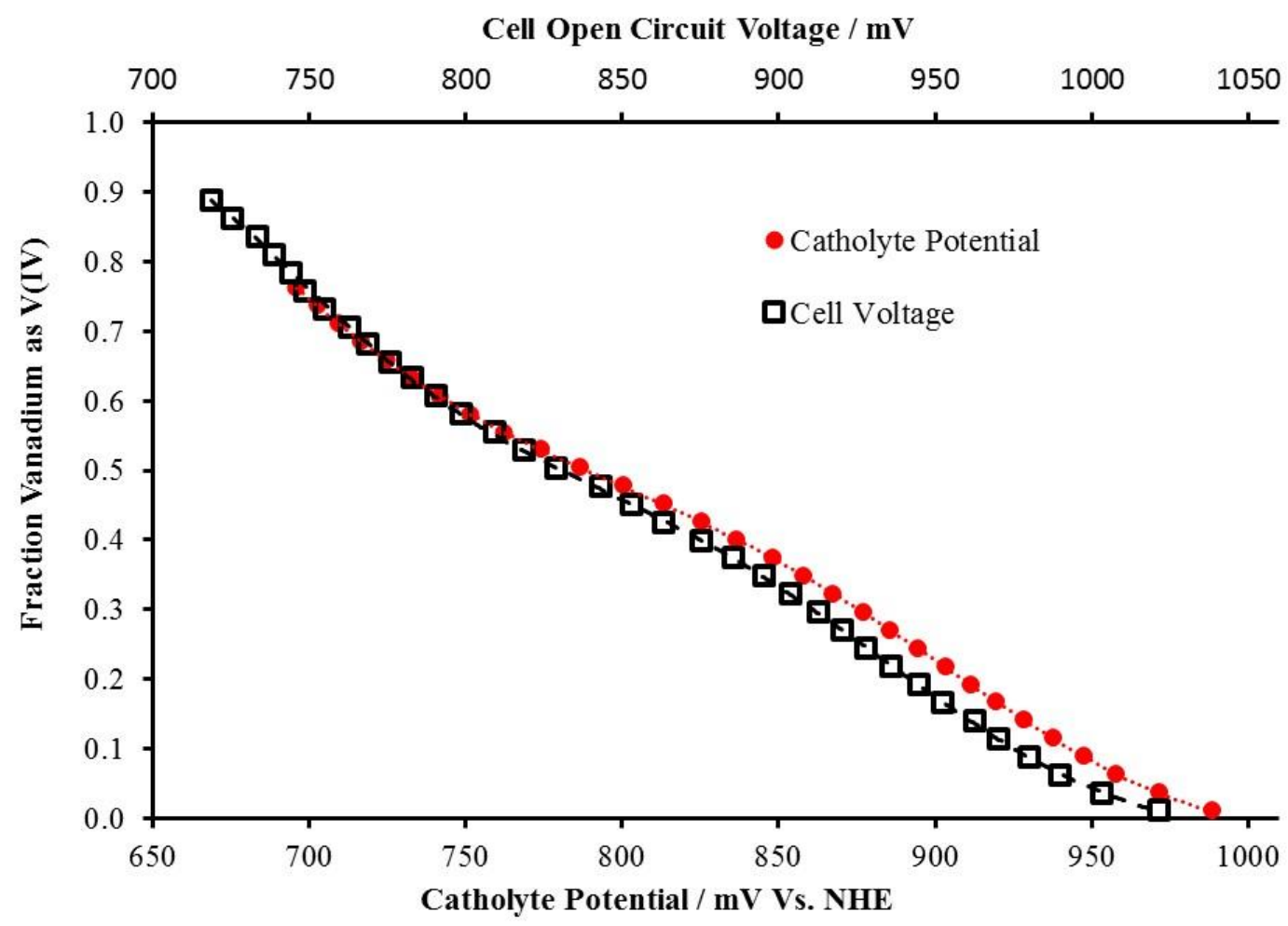

Figure 3. Relationship between the fraction of vanadium(IV) in the catholyte and its redox potential as recorded by the reference electrode and the cell at open circuit. The dotted curves are the $6^{\text {th }}$ order polynomial fitted functions.

Figure 4a illustrates the results obtained from triplicate Regeneration Sweep tests of reduced V3POM. Under a constant air flow of $1 \mathrm{~L} \mathrm{~min}^{-1}$, the catholyte redox potential increases with time as vanadium(IV) is oxidised to vanadium(V) and oxygen from the air is reduced to water. The data was then processed (as described in the previous section) to produce Figure $4 \mathrm{~b}$, where regeneration current, $I_{R}$, is plotted against vanadium(IV) fraction. As expected, the regeneration current decreases as the amount of vanadium(IV) decreases. Although some variation is observed between repeats, results are broadly similar. Compared to the line of average performance, individual curves fall within $\pm 1.3 \mathrm{~A}$ for a given value of vanadium(IV) fraction. The differences are most likely the result of changes in sparge performance (i.e. changes in mean bubble size, gas-liquid hold-up and thus, collective interfacial area for mass transfer) and/or data processing artefacts (i.e. the use of $6^{\text {th }}$ order polynomials for data fitting). Negligible regeneration reaction is observed to take place beneath a vanadium(IV) fraction of approximately 0.5 , corresponding to a maximum OCV for "ordinary" fuel cell operation of around $835 \mathrm{mV}$ (i.e. the maximum OCV achievable where oxidation 
of the catholyte is carried out via regeneration alone and not via electrochemical methods). This would suggest that during ordinary operation, at least half of the vanadium present remains in the vanadium(IV) state and exists as an "unrecoverable" fraction. This is consistent with the ${ }^{31} \mathrm{P}$ NMR results in Table 1, where approximately half of the total vanadium in fully oxidised V3-POM is present as $\left[\mathrm{PVMo}_{11} \mathrm{O}_{40}\right]^{4-},\left[\mathrm{PV}_{2} \mathrm{Mo}_{10} \mathrm{O}_{40}\right]^{5-}$ and free vanadium $\left(\mathrm{VO}_{2}{ }^{+}\right)$.

Figure $4 \mathrm{~b}$ also shows regeneration performance as determined by the Steady-State Method. As can be seen, reasonable agreement between the two methods is observed (i.e. within $\pm 1 \mathrm{~A}$ of average Sweep test performance), providing confidence in the accuracy of the results and the approach used to quantify chemical current.
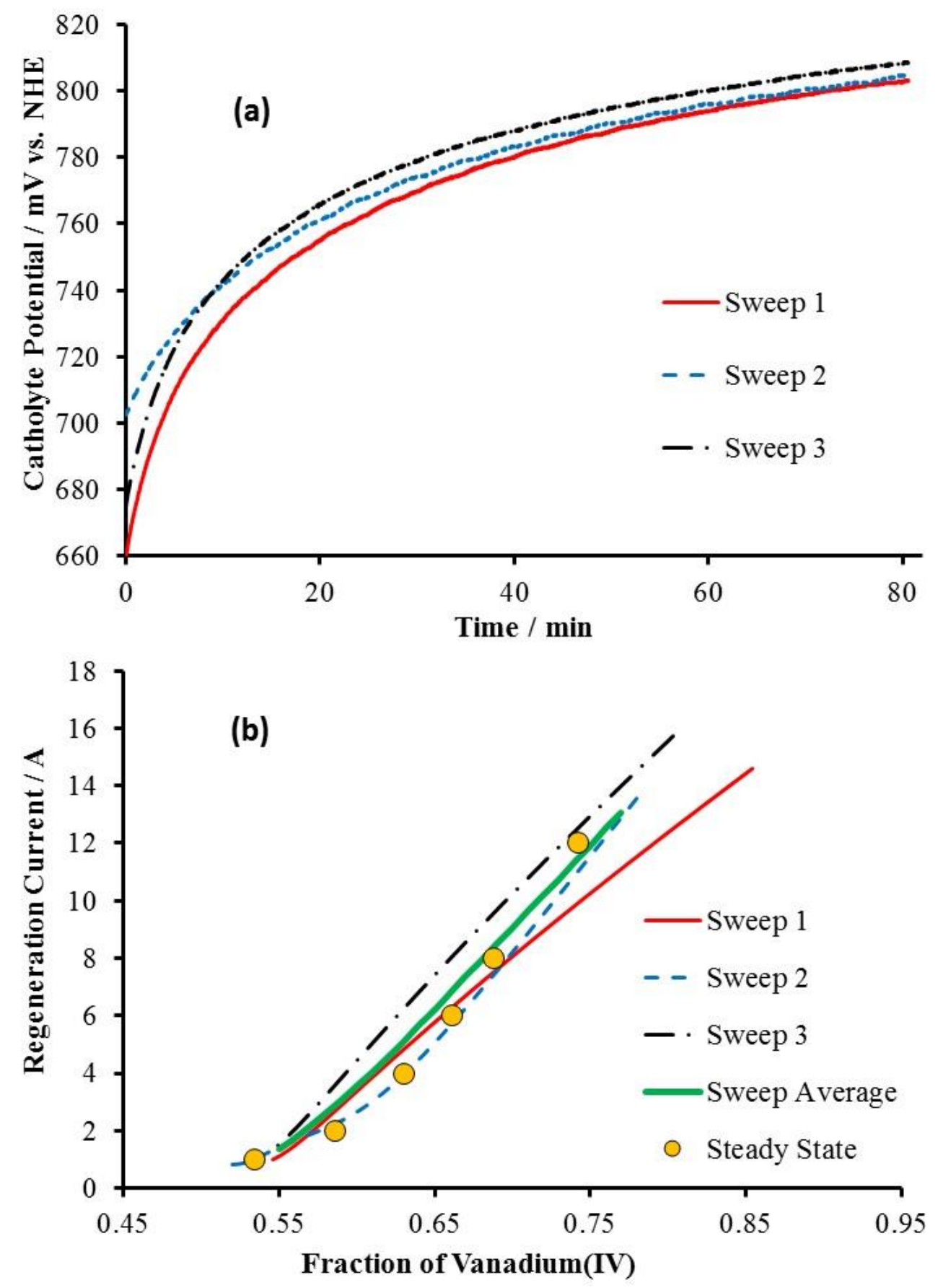

Figure 4. (a) Catholyte redox potential vs. time during regeneration sweep tests. (b) Calculated regeneration current vs. fraction of vanadium(IV). 


\subsection{Cell Performance}

I-V and power curves generated using V3-POM catholyte at varying initial inlet vanadium(IV) fractions are shown in Figure 5. As expected, cell performance is demonstrated to improve as the initial inlet fraction of vanadium(IV) decreases. On closer inspection, the I-V curves in Figure 5 a are not parallel. This may be caused by chemical changes in the catholyte as it is reduced. For example, Table 3 lists catholyte $\mathrm{pH}$ and conductivity values at the five initial inlet vanadium(IV) fractions used in Figure 5. Due to the presence of free vanadium in the catholyte (with a 1-electron, 2-proton reduction mechanism), the $\mathrm{pH}$ increases with the amount of vanadium(IV). This decrease in proton concentration results in a noticeable drop in catholyte conductivity. An investigation into the effect of changing $\mathrm{pH}$ and conductivity on the shape of the $\mathrm{I}-\mathrm{V}$ curve is underway.
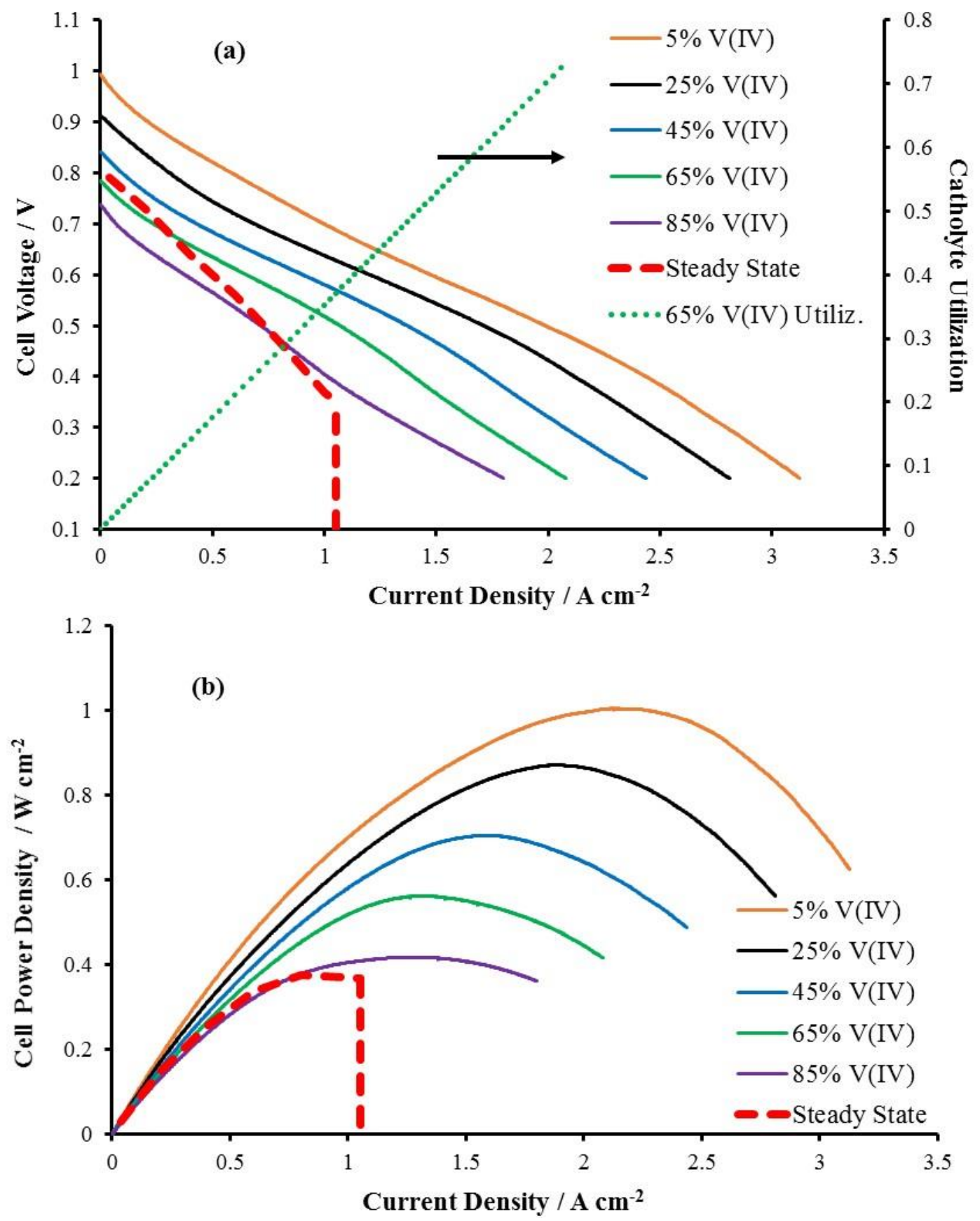

Figure 5. (a) $I-V$ and (b) corresponding power density curves generated with catholytes of varying initial inlet vanadium(IV) fractions. The predicted equivalent steady state $I-V$ performance curve is also shown (obtained using the method detailed in Section 3.3). The catholyte utilization is plotted in (a) for an initial inlet vanadium(IV) fraction of 0.65. 
Although the regenerator was active throughout the polarization measurements, in some cases it was not able to maintain a constant catholyte potential. Consequently, the redox potential of the catholyte entering the cell was not constant throughout the measurement. Table S1 lists the initial and final vanadium(IV) fractions for each of the curves in Figure 5 and the corresponding OCV values. However, as there existed a significant lag time between events (i.e. I- $V$ test completion and catholyte homogenisation), the full impact of vanadium(IV) enrichment would not have been realised at the cell inlet before the completion of each $I-V$ curve.

Also shown in Figure 3(a) is the corresponding catholyte utilization curve for the 0.65 initial inlet vanadium(IV) fraction $I-V$ curve, where a utilization of 1 corresponds to complete reduction of the inlet vanadium(V) to vanadium(IV) and a utilization of 0 corresponds to zero reduction. According to Table S1, the inlet vanadium(IV) fraction remained approximately constant for this sweep, allowing a reliable estimate of utilization. A 0.65 vanadium(IV) fraction corresponds to a total concentration of $0.315 \mathrm{M}$ vanadium( $(\mathrm{V})$, which at $140 \mathrm{~mL} \mathrm{~min}^{-1}$ can produce a maximum current density of $2.8 \mathrm{~A} \mathrm{~cm}^{-2}$ if fully consumed.

The polarization curve corresponding to an initial inlet vanadium(IV) fraction of 0.05 represents the best performance of the cell using $\mathrm{V} 3-\mathrm{POM}$ catholyte ( $0.3 \mathrm{M}$ concentration) and is compared against other cells with $\mathrm{H}_{2} / \mathrm{Pt}$ anodes from the literature in Table 4. The V3-POM fuel cell OCV is almost identical to that of conventional PEFCs. However, the CRRC fuel cell in this work does not suffer from the slow oxygen reduction electrode kinetics and thus the voltage at $0.2 \mathrm{~A} \mathrm{~cm}^{-2}$ is higher than that obtained from state-of-the-art conventional PEFCs employing a similar MEA [40,41]. As the current density increases beyond $0.2 \mathrm{~A} \mathrm{~cm}^{-2}$, the voltage of the V3-POM cell decreases faster than the conventional PEFCs until performance is almost identical at $1 \mathrm{~A} \mathrm{~cm}^{-2}$. Compared to the best performing CRRC fuel cells reported to date, the V3-POM system almost matches the performance of the nitrate system reported by $\mathrm{Han}$ et al. at low current densities [3], whereas the voltage at $1 \mathrm{~A}$ $\mathrm{cm}^{-2}$ is much higher for the V3-POM system. In addition, the maximum power of the V3-POM system is double that of the two previously reported CRRC systems and comparable to the power density of conventional PEFCs $[3,6]$. The two redox flow batteries (with $\mathrm{H}_{2} / \mathrm{Pt}$ anodes) in Table 4 also provide useful comparisons. The vanadium- $\mathrm{H}_{2}$ battery disclosed by Yufit et al. has the highest OCV in Table 4 but the cell most likely possessed a large ohmic resistance leading to a significant voltage drop at low current densities. On the other hand, the $\mathrm{Br}_{2}-\mathrm{H}_{2}$ flow battery reported by Weber and coworkers represents one of the best performing electrochemical cells in the literature and provides an idea of the best possible cell performance achievable with a CRRC PEFC. At $0.2 \mathrm{~A} \mathrm{~cm}^{-2}$, the voltage drop values for the $\mathrm{V} 3-\mathrm{POM}$ system and $\mathrm{Br}_{2}-\mathrm{H}_{2}$ cell are 90 and $80 \mathrm{mV}$, respectively, whilst at $1 \mathrm{~A} \mathrm{~cm}^{-2}$ the corresponding values are 270 and $230 \mathrm{mV}$. This suggests the CRRC cell used in this study can be further optimised to decrease voltage losses.

Maintaining the catholyte in a highly oxidised state is key to optimising cell performance. However, as discussed in Section 3.1, V3-POM cannot be regenerated below a vanadium(IV) fraction of approximately 0.5 and hence, results representing $0.05,0.25$ and 0.45 initial inlet vanadium(IV) fractions in Figure 5 are not obtainable using the present regenerator apparatus. Therefore, the 0.65 initial inlet vanadium(IV) fraction curves in Figure 5 represent the most realistic OCV and the key results for this catholyte state are also listed in Table 4. As observed, the OCV is around $200 \mathrm{mV}$ lower than that of conventional PEFCs, which leads to lower voltages at 0.2 and $1.0 \mathrm{~A} \mathrm{~cm}^{-2}$. However, the voltage at $1 \mathrm{~A} \mathrm{~cm}^{-2}$ and the maximum power density of the V3-POM system operating with a vanadium(IV) fraction of 0.65 still exceed that of the two best performing CRRC PEFC systems reported to date $[3,6]$. 
Electrochemical Impedance measurements were conducted on the V3-POM cell with an initial inlet vanadium(IV) fraction of 0.65 operating at $0.35,0.6$ and $1 \mathrm{~A} \mathrm{~cm}^{-2}$. The corresponding Nyquist plots are shown in Figure 6 and suggest the cell's area specific high frequency resistance (HFR) decreases slightly as the current increases, with an average value of around $125 \mathrm{~m} \Omega \mathrm{cm}^{2}$. This is considerably higher than the corresponding HFR values for the conventional PEFC and $\mathrm{Br}_{2}-\mathrm{H}_{2}$ flow battery in Table 4. Given the membrane material for the three cells is similar, the difference could be caused by the relatively low compression in the V3-POM cell. The pressure on the active area is approximately 4 bar compared to 8-10 bar in conventional fuel cells, suggesting one route to improve the performance of the CRRC cell. The two arcs in the Nyquist plots can be tentatively assigned to the catholyte charge transfer resistance/electrode kinetics (arc on the left) and the catholyte mass transport impedance (arc on the right). A thorough analysis of the electrochemical impedance requires a detailed parameter study and is the subject of on-going work.

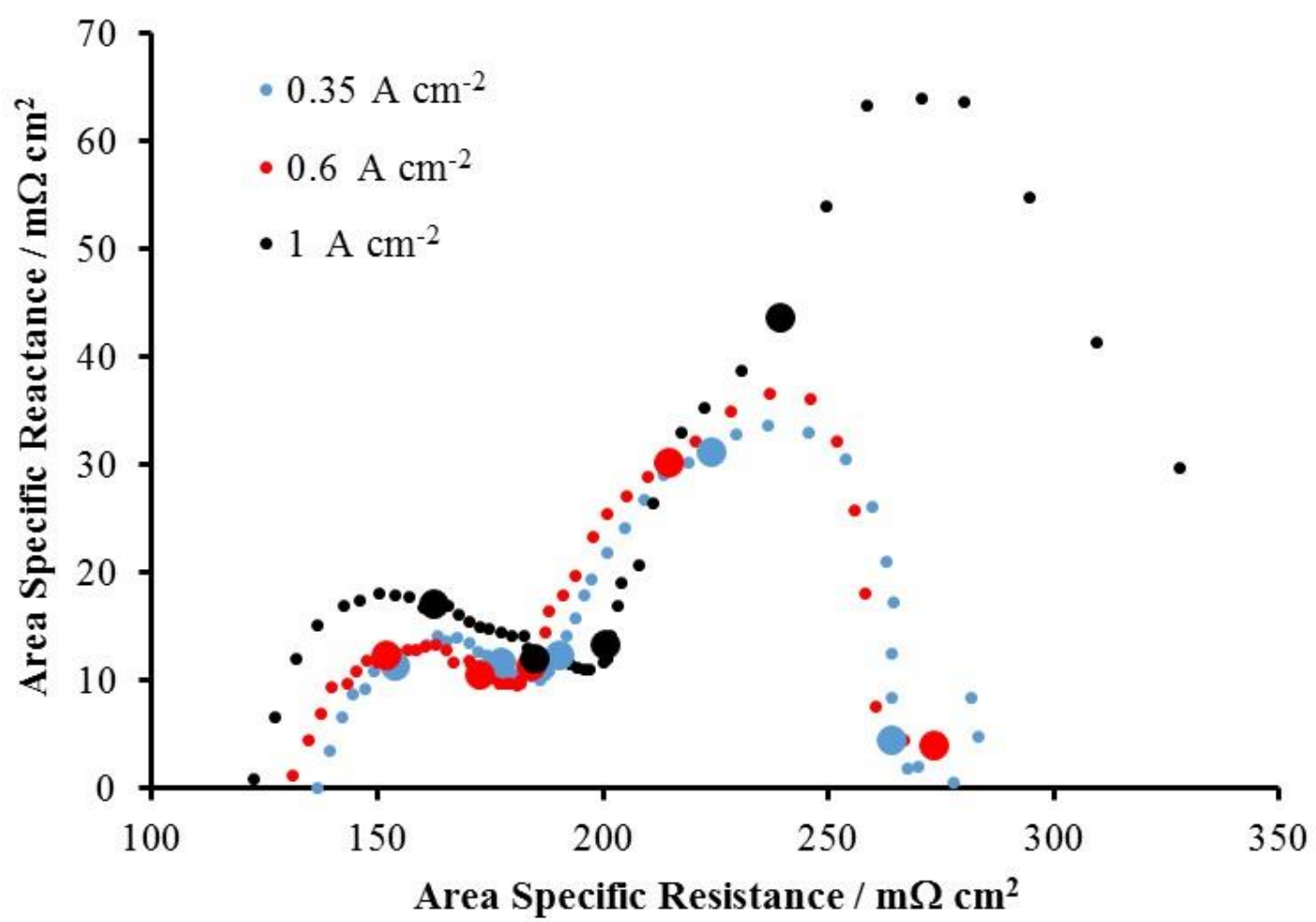

Figure 6. Nyquist plots recorded at $0.35,0.6$ and $1 \mathrm{~A} \mathrm{~cm}^{-2}(8.75,15$ and $25 \mathrm{~A})$ with the $\mathrm{V} 3-\mathrm{POM}$ catholyte at an initial inlet vanadium(IV) fraction of 0.65 . The large circles represent measurements recorded at, from left to right, $1.15 \mathrm{kHz}, 111 \mathrm{~Hz}$, $10.8 \mathrm{~Hz}, 1.05 \mathrm{~Hz}$ and $102 \mathrm{mHz}$.

\subsection{Combined System Performance}

Steady-state system performance is a product of the performance of both the cell and regenerator. By examining the performance of each in isolation, it is possible to predict the performance of the complete system. At steady-state operation, current load applied to the cell is balanced by the oxidation reaction within the regenerator (i.e. cell current, $I=$ regeneration current, $I_{R}$ ). Given a steady state current, the vanadium(IV) fraction of the catholyte can be estimated from Figure $4 \mathrm{~b}$. Next, Figure 3 is used to determine the catholyte potential. Finally, the experimental $I-V$ curves in Figure $5 \mathrm{a}$ are used to estimate the cell operating voltage for the given catholyte inlet potential and current load.

The predicted steady state $I-V$ curves are plotted in Figure $5 a$ with corresponding power profiles in Figure $5 \mathrm{~b}$ and the key results are listed in Table 4 (bottom row). Note that the entry for OCV is given 
as "Varies". In this case, OCV varies with steady state current. A prediction of the relationship between steady state current density and inlet catholyte potential (i.e. OCV) can be obtained from Figures $4(\mathrm{a})$ and $4(\mathrm{~b})$ and is plotted in Figure S6. Unlike the other curves in Figure 5, which are transient measurements, each point on the steady state curve corresponds to a situation where the chemical current of the regeneration reaction exactly matches the electrical current discharged from the cell. The fact that the steady state curve in Figure $5 a$ is steeper than the transient $I-V$ curves implies this CRRC fuel cell system is limited by the regeneration reaction. At $1 \mathrm{~A} \mathrm{~cm}^{-2}$ the steadystate cell voltage is estimated to be $0.37 \mathrm{~V}$, considerably lower than the $0.50 \mathrm{~V}$ observed for the transient I-V curve with 0.65 initial inlet vanadium(IV) fraction. Consequently, steady state power is considerably lower than the corresponding transient results. The steady state curves in Figure 5 end abruptly at $1.05 \mathrm{~A} \mathrm{~cm}^{-2}(26.25 \mathrm{~A})$, after which the predicted cell voltage falls to zero. To deliver a regeneration current of $26.25 \mathrm{~A}$ with the given catholyte and regenerator requires a vanadium(IV) fraction of 1 (obtained from extrapolating Figure $4 \mathrm{~b}$ ), i.e. complete reduction of the catholyte. This corresponds to the maximum chemical current achievable with the given system, hence the abrupt end to the steady state curves in Figure 5.

Although comparison with similar cells from the literature suggests considerable performance benefits can be gained from further optimisation of the POM-CRRC cell design, the system reported in this study is clearly limited by regenerator performance. As such, this work highlights the need for continued development in both cell design and regenerator performance. The latter is a product of both the catholyte formulation (i.e. improving the V3-POM catholyte used in this work) and the effectiveness of the regenerator (i.e. maximising the air-catholyte surface area). Indeed, improvements in regenerator performance have significant effects on the cost and size of the system by decreasing the amount of catholyte required. For example, given that the $9.4 \mathrm{~W}$ steady state peak power in this study was obtained with $0.3 \mathrm{~L}$ of catholyte, directly scaling the system to $100 \mathrm{~kW}$ (i.e. an automotive application) would require over $3000 \mathrm{~L}$ of catholyte. This clearly demonstrates there is much scope for improvement!

\section{Conclusion}

This study represents the first thorough study of a complete CRRC PEFC system, using an aqueous polyoxometalate solution as a catholyte. The catholyte, with empirical formula $\mathrm{H}_{6} \mathrm{PV}_{3} \mathrm{Mo}_{9} \mathrm{O}_{40}$, was assessed in terms of its performance within both the cell and regenerator over a range of vanadium(IV) fractions. As expected, cell performance was seen to diminish as the fraction of vanadium(IV) increased. Conversely, the rate of catholyte regeneration was demonstrated to increase with vanadium(IV) fraction. Two methods for determining regeneration rate were devised and explored, and reasonable agreement was found between the two. Expressing the regeneration rate as a "chemical" or "regeneration" current was introduced as a useful means of measuring performance with respect to the cell. Based on experimentally derived cell and regenerator performance results, a method of predicting the steady-state system performance was also devised. Peak steady-state system power density was determined to be $0.37 \mathrm{~W} \mathrm{~cm}^{-2}$ at $0.8 \mathrm{~A} \mathrm{~cm}^{-2}$ (i.e. $9.4 \mathrm{~W}$ at $20 \mathrm{~A}$ ). Although a relatively modest performance compared to conventional PEFCs, such output was generated with zero platinum on the cathode and using a cell configuration that is fundamentally more durable (i.e. no air on the cathode).

Furthermore, this investigation has also established the measurement techniques necessary for quantifying CRRC fuel cell systems (i.e. regeneration sweep and steady-state test, the concept of a regeneration current and steady-state $I-V$ and power curves) and highlighted the three key 
challenges for future work. First, the catholyte needs an achievable high open circuit voltage, fast electrode kinetics (preferably on carbon) and excellent regenerative properties (i.e. fast chemical reduction of oxygen). Second, the cell design needs to be optimized for a gaseous anode and liquid cathode. Third, the regenerator (air bubbler) needs to be both effective and efficient, delivering a fast regeneration reaction for a low parasitic energy consumption. 


\section{Glossary}

CRRC Chemically Regenerative Redox Cathode

AMA Anode Membrane Assembly

EIS Electrochemical Impedance Spectroscopy

GDL Gas Diffusion Layer

V3-POM $\quad \mathrm{H}_{6} \mathrm{PV}_{3} \mathrm{Mo}_{9} \mathrm{O}_{40}$ (empirical formula)

I-V Current-Voltage

MEA Membrane Electrode Assembly

OCV Open Circuit Voltage

PEFC Polymer Electrolyte Fuel Cell

POM Phosphomolybdovanadate polyoxoanion

NHE Normal Hydrogen Electrode

\section{Acknowledgements}

This study was part funded by the HEFCE (Higher Education Funding Council for England) Innovation Fund. The authors also thank Dr Corinne Wills (Newcastle University) for the NMR analysis and Dr Andrew Creeth (ACAL Energy), Joshua Denne (Advanced Propulsion Centre), Nadine UwigenaMudatsikira (University of Chester) and Belloumi Kangati (Addivant UK Ltd) for their advice. 


\section{References}

[1] S. Hirano, D. Papageorgopoulos, Fuel Cell Technical Team Roadmap, U.S DRIVE (June 2013).

[2] M. Jouin, M. Bressel, S. Morando, R. Gouriveau, D. Hissel, M.-C. Péra, N. Zerhouni, S. Jemei, M. Hilairet, B. Ould Bouamama, Applied Energy, 177 (2016) 87-97.

[3] S.-B. Han, Y.-J. Song, Y.-W. Lee, A.-R. Ko, J.-K. Oh, K.-W. Park, Chemical Communications, 47 (2011) 3496-3498.

[4] J. Kummer, D.-G. Oei, Journal of Applied Electrochemistry, 12 (1982) 87-100.

[5] J. Kummer, D.-G. Oei, Journal of Applied Electrochemistry, 15 (1985) 619-629.

[6] R. Singh, A.A. Shah, A. Potter, B. Clarkson, A. Creeth, C. Downs, F.C. Walsh, Journal of Power Sources, 201 (2012) 159-163.

[7] C.A. Reiser, L. Bregoli, T.W. Patterson, S.Y. Jung, J.D. Yang, M.L. Perry, T.D. Jarvi, Electrochemical and Solid-State Letters, 8 (2005) A273-A276.

[8] E. Brightman, G. Hinds, Journal of Power Sources, 267 (2014) 160-170.

[9] F.D. Coms, Ecs Transactions, 16 (2008) 235-255.

[10] E. Endoh, S. Terazono, H. Widjaja, Y. Takimoto, Electrochemical and Solid-State Letters, 7 (2004) A209-A211.

[11] K.T. Cho, M.C. Tucker, A.Z. Weber, Energy Technology, (2016).

[12] V. Yufit, B. Hale, M. Matian, P. Mazur, N. Brandon, Journal of The Electrochemical Society, 160 (2013) A856-A861.

[13] R. Pattabiraman, V. Venkatesan, H. Udupa, Journal of Scientific \& Industrial Research, 40 (1981) 432-447.

[14] J. Zhang, Y. Tang, C. Song, J. Zhang, H. Wang, Journal of power sources, 163 (2006) 532-537.

[15] K.T. Cho, P. Albertus, V. Battaglia, A. Kojic, V. Srinivasan, A.Z. Weber, Energy Technology, 1 (2013) 596-608.

[16] A. Creeth, Fuel Cells Bulletin, 2013 (2013) 12-14.

[17] Y.V. Tolmachev, M.A. Vorotyntsev, Russian Journal of Electrochemistry, 50 (2014) 403-411.

[18] E.M. T. Matsui, S. Nakada, T. Okanishi, H. Muroyama, Y. Hirao, T. Takahashi, K. Eguchi ACS Applied Materials \& Interfaces 8 (2016) p18119.

[19] W. Liu, W. Mu, Y. Deng, Angewandte Chemie, 126 (2014) 13776-13780.

[20] I.V. Kozhevnikov, Chemical Reviews, 98 (1998) 171-198.

[21] J.J. Borrás-Almenar, E. Coronado, A. Müller, M. Pope, Polyoxometalate molecular science, Springer Science \& Business Media, 2003.

[22] H.D. Pratt, N.S. Hudak, X. Fang, T.M. Anderson, Journal of Power Sources, 236 (2013) 259-264.

[23] S. Himeno, N. Ishio, Journal of Electroanalytical Chemistry, 451 (1998) 203-209.

[24] B.R. Limoges, R.J. Stanis, J.A. Turner, A.M. Herring, Electrochimica acta, 50 (2005) 1169-1179.

[25] M.S. Freund, N.S. Lewis, Inorganic Chemistry, 33 (1994) 1638-1643. 
[26] L. David, C. Crăciun, M. Rusu, O. Cozar, P. Ilea, D. Rusu, Polyhedron, 19 (2000) 1917-1923.

[27] R.D. Gall, M. Faraj, C.L. Hill, Inorganic Chemistry, 33 (1994) 5015-5021.

[28] V. Odyakov, E. Zhizhina, K. Matveev, Journal of Molecular Catalysis A: Chemical, 158 (2000) 453456.

[29] L. Pettersson, Molecular Engineering, 3 (1993) 29-42.

[30] D.S. Warren, B.M. Gimarc, M. Zhao, Inorganic Chemistry, 33 (1994) 710-715.

[31] A. Selling, I. Andersson, J.H. Grate, L. Pettersson, European Journal of Inorganic Chemistry, 2000 (2000) 1509-1521.

[32] A. Weinstock, R.H. Atalla, R.S. Reiner, M.A. Moen, K.E. Hammel, C.J. Houtman, C.L. Hill, New Journal of Chemistry, 20 (1996) 269.

[33] I.A. Weinstock, R.H. Atalla, R.S. Reiner, M.A. Moen, K.E. Hammel, C.J. Houtman, C.L. Hill, M.K. Harrup, Journal of Molecular Catalysis A: Chemical, 116 (1997) 59-84.

[34] A. Selling, I. Andersson, J.H. Grate, L. Pettersson, European Journal of Inorganic Chemistry, 2002 (2002) 743-749.

[35] V. Berdnikov, Koord. Khim, 5 (1979) 78.

[36] I. Kozhevnikov, Y.V. Burov, K. Matveev, Bulletin of the Academy of Sciences of the USSR, Division of chemical science, 30 (1981) 2001-2007.

[37] E. Zhizhina, V. Odyakov, M. Simonova, K. Matveev, Kinetics and catalysis, 46 (2005) 354-363.

[38] N. Martin, M. Herbert, Synthesis of Polyoxometalates, WO2015/097459 A1.

[39] T. Davies, J. Denne, N.B. Baynes, Redox Probe, GB 2527104 (A).

[40] H.A. Gasteiger, S.S. Kocha, B. Sompalli, F.T. Wagner, Applied Catalysis B: Environmental, 56 (2005) 9-35.

[41] GORE ${ }^{\mathrm{TM}} \quad$ PRIMEA $^{\circledast}$ SERIES 57 MEAs, 2003, https://www.gore.com/MungoBlobs/387/750/primea 57 mea datasheet.pdf.

[42] R.E.G. Smith, T.J. Davies, N. de B. Baynes, R.J. Nichols, Journal of Electroanalytical Chemistry, 747 (2015) 29-38. 


\section{Figure Captions}

Figure 1. Schematic describing the CRRC process and including the reactions that occur within the cell, regenerator and catholyte solution.

Figure 2. Representation of the $\alpha$-keggin structure $\left[\mathrm{PMo}_{12} \mathrm{O}_{40}\right]^{3-}$ with phosphorous in green, molybdenum in blue and oxygen in red. In $\left[\mathrm{PV}_{3} \mathrm{Mo}_{9} \mathrm{O}_{40}\right]^{6-}$ three vanadium atoms replace three molybdenum atoms (the hydrogens are omitted for clarity).

Figure 3. Relationship between the fraction of vanadium(IV) in the catholyte and its redox potential as recorded by the reference electrode and the cell at open circuit. The dotted curves are the $6^{\text {th }}$ order polynomial fitted functions.

Figure 4. (a) Catholyte redox potential vs. time during regeneration sweep tests. (b) Calculated regeneration current vs. fraction of vanadium(IV).

Figure 5. (a) $I-V$ and (b) corresponding power density curves generated with catholytes of varying initial inlet vanadium(IV) fractions. The predicted equivalent steady state $I-V$ performance curve is also shown (obtained using the method detailed in Section 3.3). The catholyte utilization is plotted in (a) for an initial inlet vanadium(IV) fraction of 0.65 .

Figure 6. Nyquist plots recorded at $0.35,0.6$ and $1 \mathrm{~A} \mathrm{~cm}^{-2}(8.75,15$ and $25 \mathrm{~A})$ with the V3-POM catholyte at an initial inlet vanadium(IV) fraction of 0.65 . The large circles represent measurements recorded at, from left to right, $1.15 \mathrm{kHz}, 111 \mathrm{~Hz}, 10.8 \mathrm{~Hz}, 1.05 \mathrm{~Hz}$ and $102 \mathrm{mHz}$.

\section{Table Captions}

Table 1. Speciation of V3-POM catholyte at $298 \mathrm{~K}$ estimated from ${ }^{31} \mathrm{P}$ NMR analysis.

Table 2: General test rig operating conditions.

Table 3: Target fractions of vanadium(IV) and corresponding redox potentials, open circuit voltages, $\mathrm{pH}$ and conductivity values at $80^{\circ} \mathrm{C}$.

Table 4: Comparison of V3-POM CRRC fuel cell performance (last three rows) with previously reported results from electrochemical cells with hydrogen anodes. 


\section{Tables}

Table 1. Speciation of V3-POM catholyte at $298 \mathrm{~K}$ estimated from ${ }^{31} \mathrm{P}$ NMR analysis.

\begin{tabular}{ccc}
\hline Species* & Fraction of Phosphorous & Concentration / M \\
\hline $\mathrm{PO}_{4}$ & 0.044 & 0.013 \\
$\mathrm{PV}_{1} \mathrm{Mo}_{11} \mathrm{O}_{40}$ & 0.048 & 0.014 \\
$\mathrm{PV}_{2} \mathrm{Mo}_{10} \mathrm{O}_{40}$ & 0.443 & 0.133 \\
$\mathrm{PV}_{3} \mathrm{Mo}_{9} \mathrm{O}_{40}$ & 0.345 & 0.1035 \\
$\mathrm{PV}_{4} \mathrm{Mo}_{8} \mathrm{O}_{40}$ & 0.120 & 0.036 \\
Free vanadium $\left(\mathrm{VO}_{2}{ }^{+}\right)$ & 0 & 0.165
\end{tabular}

*This includes protonated, partially protonated and fully deprotonated forms. 
Table 2: General test rig operating conditions.

\begin{tabular}{ll}
\hline Parameter & Standard Condition \\
\hline Catholyte temperature & $80^{\circ} \mathrm{C}$ \\
Catholyte system volume & $300 \mathrm{~mL}$ \\
Catholyte concentration & $0.3 \mathrm{M}$ \\
Anode hydrogen pressure & $1000 \mathrm{mbar}$ \\
Anode purge duration & $1 \mathrm{~s}$ \\
Anode purge interval & $120 \mathrm{~s}$ \\
Regenerator air flow & $1 \mathrm{~L} \mathrm{~min}^{-1}$ \\
Fuel cell temperature & $80^{\circ} \mathrm{C}$ \\
Catholyte flow rate & $140 \mathrm{~mL} \mathrm{~min}^{-1}$ \\
\hline
\end{tabular}


Table 3: Target fractions of vanadium(IV) and corresponding redox potentials, open circuit voltages, $\mathrm{pH}$ and conductivity values at $80^{\circ} \mathrm{C}$.

\begin{tabular}{ccccc}
\hline $\begin{array}{c}\text { Target } \\
\text { V(IV) } \\
\text { fraction }\end{array}$ & $\begin{array}{c}\text { Catholyte Potential / } \\
\mathbf{m V} \text { vs. NHE }\end{array}$ & $\begin{array}{c}\text { Cell Open Circuit } \\
\text { Voltage / } \mathbf{~ m V}\end{array}$ & $\mathbf{p H}$ & $\begin{array}{c}\text { Conductivity / } \\
\mathbf{m S ~ c m}^{\mathbf{- 1}}\end{array}$ \\
\hline 0.05 & 317 & 997 & 0.34 & 396 \\
0.25 & 234 & 925 & 0.35 & 278 \\
0.45 & 157 & 854 & 0.40 & 197 \\
0.65 & 88 & 776 & 0.58 & 142 \\
0.85 & 32 & 728 & 0.76 & 121 \\
\hline
\end{tabular}


Table 4: Comparison of V3-POM CRRC fuel cell performance (last three rows) with previously reported results from electrochemical cells with hydrogen anodes.

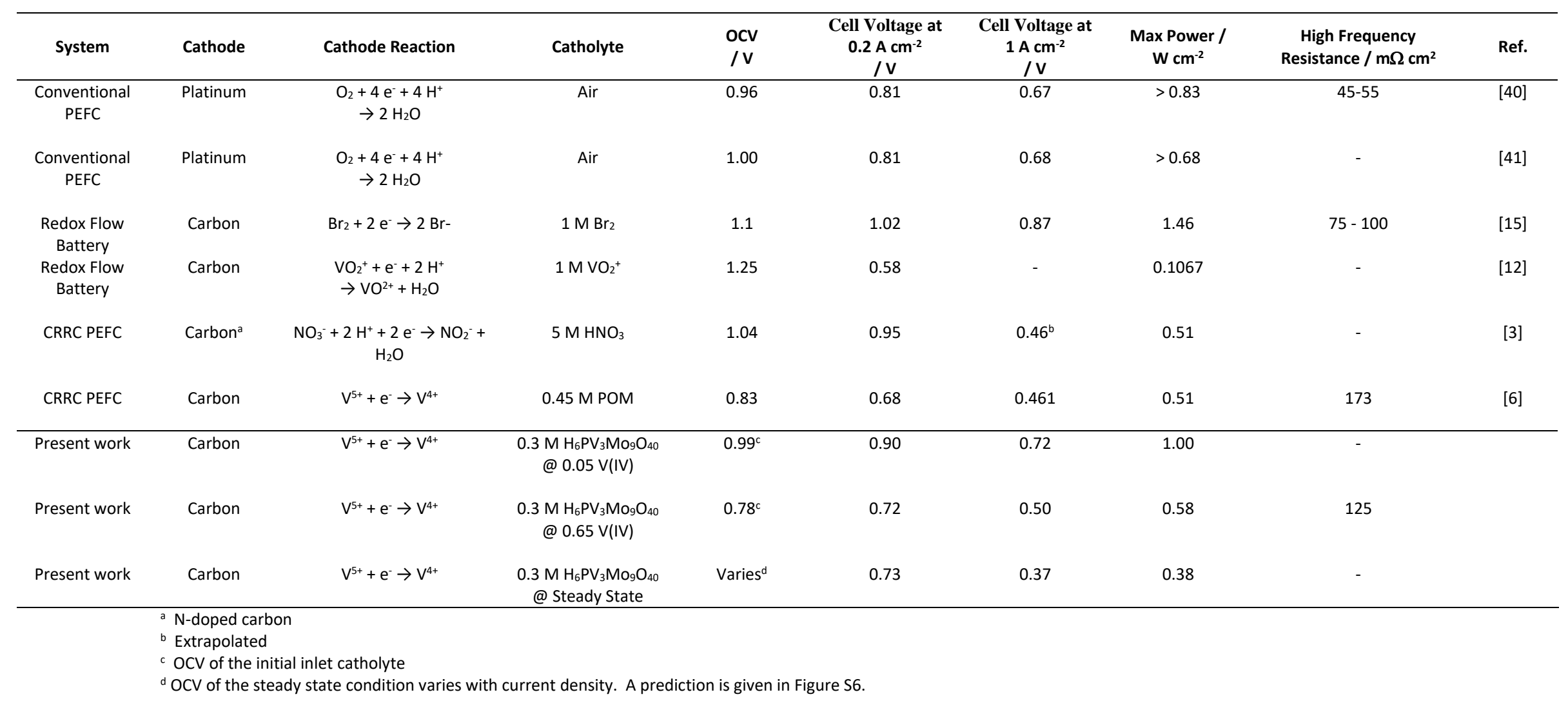

